$\begin{array}{lllll}\text { O1 } & 0.7861(4) & 1 / 4 & 0.7584(3) & 0.0362(8) \\ \text { O2 } & 0.5942(3) & 0.3614(3) & 0.7124(2) & 0.0359(6) \\ \text { K1 } & 0.08386(11) & 3 / 4 & 0.03730(8) & 0.0280(2) \\ \text { K2 } & 0.12267(9) & 0.49576(8) & 0.31771(6) & 0.03523(18)\end{array}$

Table 2. Selected geometric parameters $\left(\AA,^{\circ}\right)$ for $(1)$

$\begin{array}{llll}\mathrm{Zn}-\mathrm{Cl} 3 & 2.2509(10) & \mathrm{N}-\mathrm{O} 2 & 1.246(3) \\ \mathrm{Zn}-\mathrm{Cl1} & 2.2676(14) & \mathrm{N}-\mathrm{O} 1 & 1.247(5) \\ \mathrm{Zn}-\mathrm{Cl} 2 & 2.2784(14) & & \\ \mathrm{Cl} 3-\mathrm{Zn}-\mathrm{Cl} 3^{\mathrm{i}} & 110.63(6) & \mathrm{Cl} 1-\mathrm{Zn}-\mathrm{Cl} 2 & 106.79(6) \\ \mathrm{Cl} 3-\mathrm{Zn}-\mathrm{Cl1} & 110.41(4) & \mathrm{O} 2-\mathrm{N}-\mathrm{O} 2 & 120.9(4) \\ \mathrm{Cl} 3-\mathrm{Zn}-\mathrm{Cl} 2 & 109.26(3) & \mathrm{O} 2-\mathrm{N}-\mathrm{O} 1 & 119.50(18)\end{array}$

Symmetry code: (i) $x, \frac{1}{2}-y, z$.

\section{Compound (2)}

Crystal data

$\left(\mathrm{NH}_{4}\right)_{3}\left[\mathrm{ZnCl}_{4}\right] \mathrm{NO}_{3}$

$M_{r}=323.31$

Orthorhombic

\section{Pnma}

$a=9.268$ (3) $\AA$

$b=10.042(3) \AA$

$c=12.482(3) \AA$

$V=1161.7(6) \AA^{3}$

$Z=4$

$D_{x}=1.849 \mathrm{Mg} \mathrm{m}^{-3}$

$D_{m}=1.8(1) \mathrm{Mg} \mathrm{m}^{-3}$

$D_{m}$ measured by flotation

\section{Data collection}

Syntex $P 2_{1}$ diffractometer

$\theta-2 \theta$ scans

Absorption correction:

$\psi$ scan (Sheldrick, 1990)

$T_{\min }=0.523, T_{\max }=0.645$

1962 measured reflections

1962 independent reflections

1962 reflections with

$$
I>0
$$

\section{Refinement}

Refinement on $F^{2}$

$R\left[F^{2}>2 \sigma\left(F^{2}\right)\right]=0.043$

$w R\left(F^{2}\right)=0.105$

$S=1.090$

1962 reflections

83 parameters

Only coordinates of $\mathrm{H}$ atoms refined
Mo $K \alpha$ radiation

$\lambda=0.71073 \AA$

Cell parameters from 24 reflections

$\theta=16.3-21.6^{\circ}$

$\mu=3.015 \mathrm{~mm}^{-1}$

$T=293$ (2) K

Hexagonal prism

$0.5 \times 0.5 \times 0.5 \mathrm{~mm}$

Colorless

$$
\begin{aligned}
& \theta_{\max }=31.06^{\circ} \\
& h=0 \rightarrow 13 \\
& k=0 \rightarrow 14 \\
& l=0 \rightarrow 18 \\
& 3 \text { standard reflections } \\
& \quad \text { every } 75 \text { reflections } \\
& \text { intensity decay: none }
\end{aligned}
$$

$$
\begin{aligned}
& w= 1 /\left[\sigma^{2}\left(F_{o}^{2}\right)+(0.0553 P)^{2}\right. \\
&+0.5098 P] \\
& \text { where } P=\left(F_{o}^{2}+2 F_{c}^{2}\right) / 3
\end{aligned}
$$$$
(\Delta / \sigma)_{\max }=0.093
$$

$\Delta \rho_{\max }=0.509{\mathrm{e} \AA^{-3}}^{-3}$

$\Delta \rho_{\min }=-0.808{\mathrm{e} \AA^{-3}}^{-3}$

Extinction correction: none

Scattering factors from

Table 4. Selected geometric parameters $\left(\AA,^{\circ}\right)$ for $(2)$

$\mathrm{Zn}-\mathrm{Cl} 3 \quad 2.2489(9) \quad \mathrm{N}-\mathrm{O} 2 \quad 1.243(3)$

$\mathrm{Zn}-\mathrm{Cll} \quad 2.2783(12) \quad \mathrm{N}-\mathrm{Ol} \quad 1.243(4)$

$\mathrm{Zn}-\mathrm{Cl} 2$

$\mathrm{Cl} 3-\mathrm{Zn}-\mathrm{Cl}^{\mathrm{i}} \quad 112.96(5) \quad \mathrm{Cll}-\mathrm{Zn}-\mathrm{Cl} 2 \quad 107.45(5)$

$\mathrm{Cl} 3-\mathrm{Zn}-\mathrm{Cll} \quad 109.66(3) \quad \mathrm{O}^{2}-\mathrm{N}-\mathrm{O} 2 \quad 120.3(3)$

$\mathrm{Cl} 3-\mathrm{Zn}-\mathrm{Cl} 2 \quad 108.47(3) \quad \mathrm{O} 2-\mathrm{N}-\mathrm{Ol} \quad 119.76(16)$

Symmetry code: (i) $x, \frac{1}{2}-y, z$.

For both compounds, data collection: $P 3 / P C$ (Siemens, 1993); cell refinement: $P 3 / P C$; data reduction: $X D I S K$ in $P 3 / P C$; program(s) used to solve structures: SHELXTL-Plus (Sheldrick, 1990); program(s) used to refine structures: SHELXL97 (Sheldrick, 1997); molecular graphics: SHELXTL-Plus; software used to prepare material for publication: SHELXL97.

Supplementary data for this paper are available from the $\mathrm{IUCr}$ electronic archives (Reference: BR1211). Services for accessing these data are described at the back of the journal.

\title{
References
}

Choi, C. S., Mapes, J. E. \& Prince, E. (1972). Acta Cryst. B28, $1357-$ 1361.

Holden, J. R. \& Dickinson, C. W. (1975). J. Phys. Chem. 79, 249-256.

Lucas, B. W., Ahtee, M. \& Hewat, A. W. (1979). Acta Cryst. B35, 1038-1041.

Mikhail, I. (1980). Acta Crist. B36, 2126-2128.

Mikhail, I. \& Peters, K. (1979). Acta Cryst. B35, 1200-1201.

Nimmo, J. K. \& Lucas, B. W. (1973). J. Phys. C: Solid State Phys. 6, 201-211.

Sheldrick, G. M. (1990). SHELXTL-Plus. Structure Determination Software Programs. Siemens Analytical X-ray Instruments Inc., Madison, Wisconsin, USA.

Sheldrick, G. M. (1997). SHELXL97. Program for the Refinement of Cn'stal Structures. University of Göttingen, Germany.

\begin{tabular}{|c|c|c|c|c|}
\hline $\mathrm{Zn}$ & $\begin{array}{c}x \\
0.82143(5)\end{array}$ & $1 / 4$ & $\begin{array}{c}z \\
0.40896(3)\end{array}$ & $\begin{array}{c}U_{\mathrm{cq}} \\
0.02825(13)\end{array}$ \\
\hline $\mathrm{Cl1}$ & $1.03141(11)$ & $1 / 4$ & $0.50387(9)$ & $0.0444(3)$ \\
\hline $\mathrm{Cl} 2$ & $0.88055(13)$ & $1 / 4$ & $0.23134(7)$ & $0.0426(2)$ \\
\hline $\mathrm{Cl} 3$ & $0.69644(9)$ & $0.06329(7)$ & $0.44482(6)$ & $0.04310(19)$ \\
\hline $\mathrm{N}$ & $0.6591(3)$ & $1 / 4$ & $0.7273(2)$ & $0.0265(6)$ \\
\hline 01 & $0.7858(3)$ & $1 / 4$ & $0.7601(3)$ & $0.0521(8)$ \\
\hline $\mathrm{O} 2$ & $0.5980(2)$ & $0.3574(2)$ & $0.7072(2)$ & $0.0502(6)$ \\
\hline $\mathrm{NI}$ & $0.0879(4)$ & $3 / 4$ & $0.0313(3)$ & $0.0357(7)$ \\
\hline $\mathrm{N} 2$ & $0.1194(4)$ & $0.4942(3)$ & $0.3220(2)$ & $0.0441(6)$ \\
\hline
\end{tabular}

Siemens (1993). P3/PC. Data Collection Software for the P3/PC Sistem. Version 4.2. Siemens Analytical X-ray Instruments Inc., Madison, Wisconsin, USA.

Zompa, L. J. (1999). In preparation.

Zompa, L. J. \& Haidar, R. (1996). Acta Cryst. C52, 1188-1190.

International Tables for

Crystallography (Vol. C)

Table 3. Fractional atomic coordinates and equivalent isotropic displacement parameters $\left(\AA^{2}\right)$ for $(2)$

$$
U_{\mathrm{eq}}=(1 / 3) \sum_{i} \sum_{j} U^{i j} a^{i} a^{j} \mathbf{a}_{i} \cdot \mathbf{a}_{j} .
$$

Acta Cryst. (1999). C55, 8-11

\section{$\mathrm{Na}_{2} \mathrm{Mg}\left(\mathrm{SO}_{4}\right)_{2} \cdot 4 \mathrm{H}_{2} \mathrm{O}$, the $\mathrm{Mg}$ end-member of the bloedite-type of mineral}

\section{Carmen Vizcayno and M. Teresa Garcla-Gonzalez}

Centro de Ciencias Medioambientales-CSIC, Departamento de Geoquimica y Mineralogia, Serrano 115, E-28006

Madrid,Spain.E-mail:mtgg@fresno.csic.es

(Received I June 1998; accepted 19 August 1998)

\section{Abstract}

The crystal structure of a natural sample of disodium magnesium bis(sulfate) tetrahydrate, $\mathrm{Na}_{2} \mathrm{Mg}\left(\mathrm{SO}_{4}\right)_{2}$-$4 \mathrm{H}_{2} \mathrm{O}$, the $\mathrm{Mg}$ end-member of the bloedite-type of min- 
eral, is reported. The structure can be described in terms of parallel layers built up of $\mathrm{MgO}_{2}\left(\mathrm{H}_{2} \mathrm{O}\right)_{4}$ and $\mathrm{NaO}_{4}\left(\mathrm{H}_{2} \mathrm{O}\right)_{2}$ octahedra. Octahedral layers are interconnected through $\mathrm{SO}_{4}$ tetrahedra. The two crystallographically independent water molecules give rise to a threedimensional network of hydrogen bonds.

\section{Comment}

The structure of bloedite (astrakhanite) was reported by Rumanova \& Malitskaja (1959) in terms of a twodimensional structure determination. It corresponds to the $\mathrm{Mg}$ end-member of the bloedite-type of mineral, which are known to be isotypic for $\mathrm{Mg}, \mathrm{Zn}, \mathrm{Fe}, \mathrm{Ni}$ and Co end-members; see also Giglio (1958), Bukin \& Nozik (1974) and Nozik \& Fykin (1980) for the Zn end-member, and Bukin \& Nozik (1975) for the Co endmember.

The final X-ray model and the atomic labelling of the asymmetric unit are shown in Fig. 1 (ORTEP; Johnson, 1965). The structure can be described in terms of layers built up by $\mathrm{MgO}_{2}\left(\mathrm{H}_{2} \mathrm{O}\right)_{4}$ and $\mathrm{NaO}_{4}\left(\mathrm{H}_{2} \mathrm{O}\right)_{2}$ octahedra lying on the (001) planes (Fig. 2). These layers contain infinite chains of alternating $\mathrm{MgO}_{2}\left(\mathrm{H}_{2} \mathrm{O}\right)_{4}$ and $\mathrm{NaO}_{4}\left(\mathrm{H}_{2} \mathrm{O}\right)_{2}$ octahedra sharing corners, and pairs of $\mathrm{NaO}_{4}\left(\mathrm{H}_{2} \mathrm{O}\right)_{2}$ octahedra sharing one edge. Adjacent octahedral layers are interconnected by $\mathrm{SO}_{4}$ tetrahedra.

The water molecules also play an important role in the crystal packing. They form a three-dimensional network of hydrogen bonds, some of them bifurcated, involving all $\mathrm{O}$ atoms of the sulfate group (Fig. 3). Atoms $\mathrm{O} 1$ and $\mathrm{O} 4$ are involved in strong hydrogen

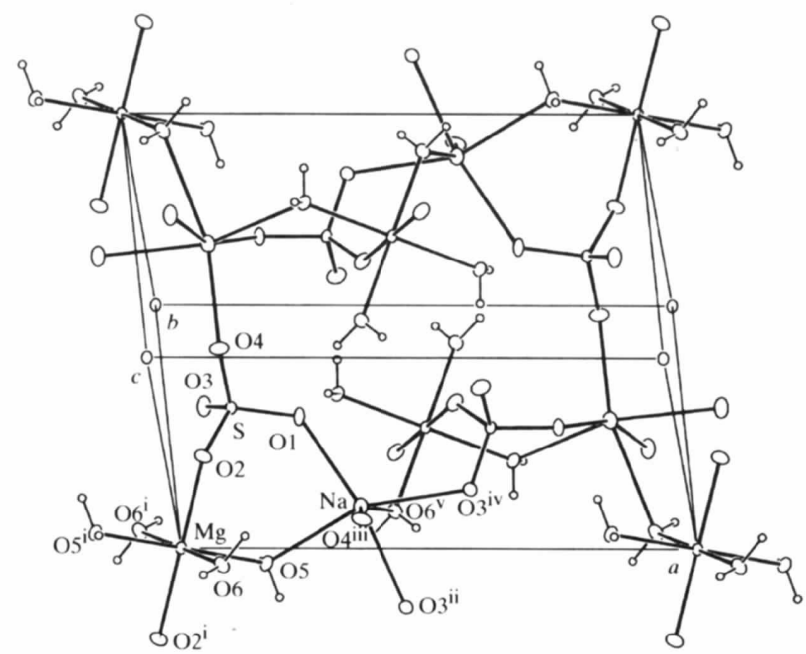

Fig. 1. Projection of the title structure showing the atom labels. Displacement ellipsoids are drawn at the $50 \%$ probability level. The atoms bonded to $\mathrm{Mg}$ at the cell corners $(0,1,0),(0,0,1),(1,0,1)$ and $(1,1,0)$ are not drawn for clarity. Symmetry codes: (i) $-x, y,-z$; (ii) $\frac{1}{2}+x, \frac{1}{2}-y, z$; (iii) $\frac{1}{2}-x, y-\frac{1}{2}, 1-z$; (iv) $\frac{1}{2}-x, y-\frac{1}{2},-z$; (v) $\frac{1}{2}-x, \frac{1}{2}+y,-z$. bonds and therefore have the largest $\mathrm{S}-\mathrm{O}$ distances, whereas atoms $\mathrm{O} 2$ and $\mathrm{O} 3$ are only weakly bonded to H52 and H61, respectively, through bifurcated contacts (details are given in Table 3).

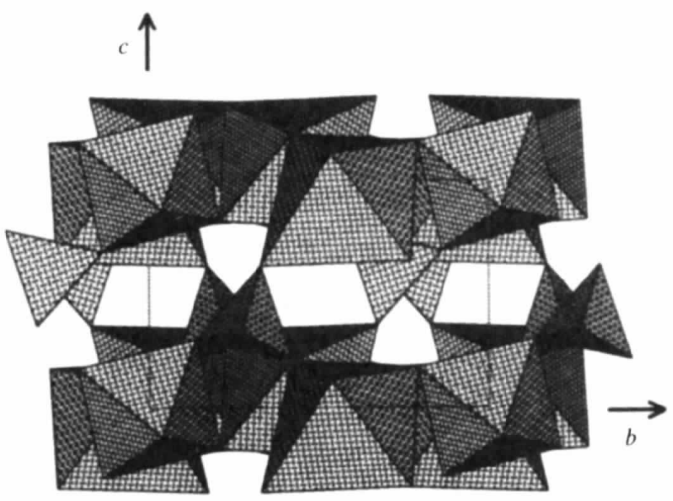

(a)

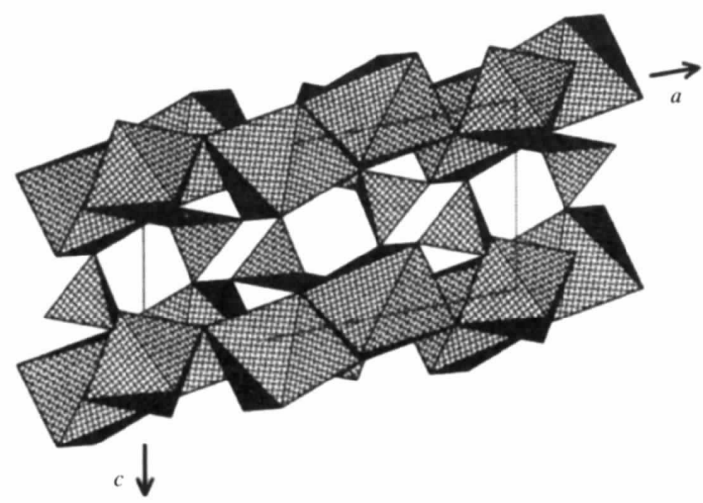

(b)

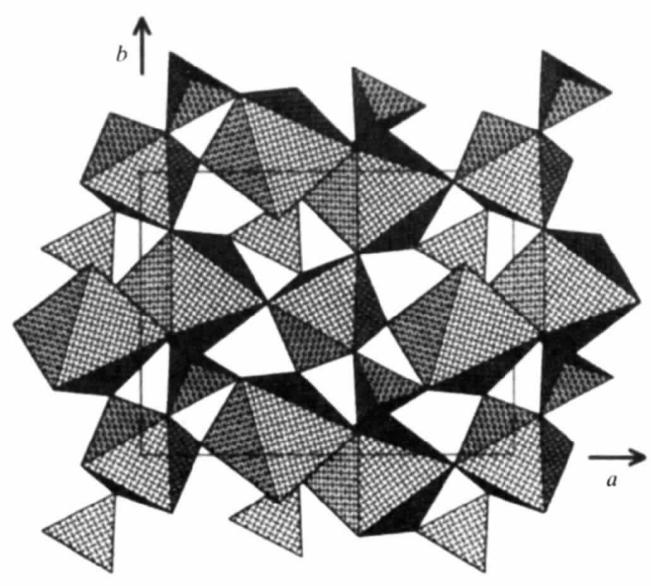

(c)

Fig. 2. Projections of the title structure showing the layers of $\mathrm{MgO}_{2}\left(\mathrm{H}_{2} \mathrm{O}\right)_{4}$ and $\mathrm{NaO}_{4}\left(\mathrm{H}_{2} \mathrm{O}\right)_{2}$ octahedra and the $\mathrm{SO}_{4}$ tetrahedra linking two adjacent octahedral layers $(a)$ down the $a$ axis, $(b)$ down the $b$ axis and (c) down the $c$ axis. 


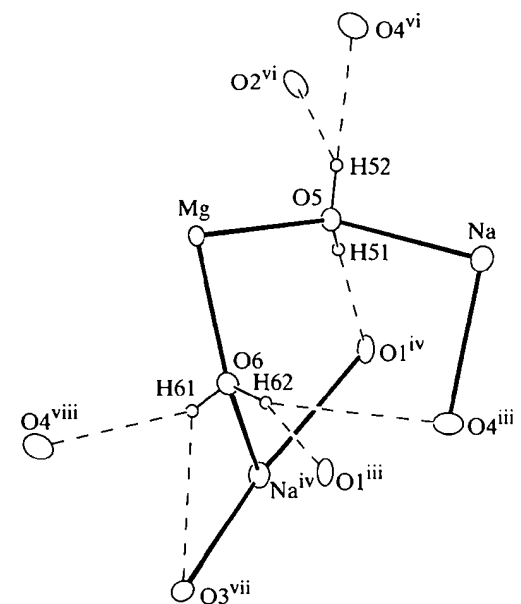

Fig. 3. Network of hydrogen bonds (symmetry codes as in Table 3).

\section{Experimental}

$\mathrm{Mg}$-bloedite is a soluble saline mineral frequently identified in soil-salt efflorescences in many parts of the world. Vizcayno et al. (1995) found this mineral in the Ebro Valley Basin, north-eastern Spain, in surface evaporitic accumulations. Two types of these accumulations were distinguished, one type consists of microcrystalline efflorescences formed through capillary evaporation, and the other type consists of saline crusts formed through surface-water evaporation. Although $\mathrm{Mg}$-bloedite is present in both types of accumulations, we have only succeeded in isolating a single crystal from a saline crust.

\section{Crystal data}

$\mathrm{Na}_{2} \mathrm{Mg}\left(\mathrm{SO}_{4}\right)_{2} \cdot 4 \mathrm{H}_{2} \mathrm{O}$

$M_{r}=334.47$

Monoclinic

$P 2_{1} / a$

$a=11.129(1) \AA$

$b=8.247(1) \AA$

$c=5.5395(3) \AA$

$\beta=100.88(1)^{\circ}$

$V=499.28(8) \AA^{3}$

$Z=2$

$D_{x}=2.225 \mathrm{Mg} \mathrm{m}^{-3}$

$D_{m}$ not measured

\section{Data collection}

Four-circle PW1100 diffractometer

$\omega / 2 \theta$ scans

Absorption correction: none

1024 measured reflections

883 independent reflections

871 reflections with

$I>2 \sigma(I)$

\section{Refinement}

Refinement on $F^{2}$ $R\left[F^{2}>2 \sigma\left(F^{2}\right)\right]=0.0289$ $w R\left(F^{2}\right)=0.0790$

$(\Delta / \sigma)_{\max }<0.001$

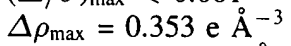

$\Delta \rho_{\min }=-0.589{\mathrm{e} \AA^{-3}}^{-3}$
$S=1.207$

883 reflections

95 parameters

All $\mathrm{H}$ atoms refined $\begin{aligned} w= & 1 /\left[\sigma^{2}\left(F_{o}^{2}\right)+(0.0437 P)^{2}\right. \\ & +0.5203 P]\end{aligned}$

where $P=\left(F_{o}^{2}+2 F_{c}^{2}\right) / 3$

Extinction correction: none

Scattering factors from

International Tables for

Crystallography (Vol. C)

Table 1. Fractional atomic coordinates and equivalent isotropic displacement parameters $\left(\AA^{2}\right)$

\begin{tabular}{lllll}
\multicolumn{5}{c}{$U_{\text {eq }}=(1 / 3) \sum_{i} \sum_{j} U^{i j} a^{i} a^{j} \mathbf{a}_{i} \cdot \mathbf{a}_{j}}$. \\
S & \multicolumn{1}{c}{$x$} & \multicolumn{1}{c}{$y$} & \multicolumn{1}{c}{$z$} & $U_{\text {eq }}$ \\
$\mathrm{Mg}$ & $0.13642(4)$ & $0.29066(6)$ & $0.36936(9)$ & $0.0116(2)$ \\
$\mathrm{Na}$ & 0 & 0 & 0 & $0.0117(3)$ \\
O1 & $0.36171(8)$ & $0.07038(11)$ & $0.1308(2)$ & $0.0212(3)$ \\
O2 & $0.26635(13)$ & $0.2713(2)$ & $0.3476(3)$ & $0.0205(4)$ \\
O3 & $0.07049(15)$ & $0.1370(2)$ & $0.3057(3)$ & $0.0204(4)$ \\
O4 & $0.08003(14)$ & $0.4211(2)$ & $0.2091(3)$ & $0.0217(4)$ \\
O5 & $0.13223(15)$ & $0.3284(2)$ & $0.6292(3)$ & $0.0217(4)$ \\
O6 & $0.16021(14)$ & $0.0376(2)$ & $-0.1271(3)$ & $0.0165(4)$ \\
& $0.0810(2)$ & $-0.2085(2)$ & $0.1771(3)$ & $0.0185(4)$
\end{tabular}

Table 2. Selected geometric parameters $\left(\AA^{\circ}{ }^{\circ}\right)$

\begin{tabular}{|c|c|c|c|c|}
\hline-03 & $1.459(2)$ & & $2.387(2)$ \\
\hline $\mathrm{S}-\mathrm{O} 2$ & $1.473(2)$ & \multicolumn{2}{|c|}{$\mathrm{Na}-\mathrm{O} 4^{11 \prime \prime}$} & $2.392(2)$ \\
\hline $\mathrm{S}-\mathrm{O} 4$ & $1.482(2)$ & \multicolumn{2}{|l|}{$\mathrm{Na}-\mathrm{Ol}$} & $2.408(2)$ \\
\hline $\mathrm{S}-\mathrm{Ol}$ & $1.4821(15)$ & \multicolumn{2}{|l|}{$\mathrm{Na}-\mathrm{O} 5$} & $2.436(2)$ \\
\hline $\mathrm{Mg}-\mathrm{OS}(\times 2)$ & $2.0602(15)$ & \multicolumn{2}{|l|}{$\mathrm{Na}-\mathrm{O}^{\prime \prime}$} & $2.438(2)$ \\
\hline $\mathrm{Mg}-\mathrm{O} 2(\times 2)$ & $2.0636(15)$ & \multicolumn{2}{|l|}{$\mathrm{Na}-\mathrm{O}^{\prime}$} & $2.655(2)$ \\
\hline $\mathrm{Mg}-\mathrm{O} 6(\times 2)$ & \multicolumn{3}{|l|}{$2.098(2)$} & \\
\hline \multicolumn{5}{|c|}{$\begin{array}{l}\text { Symmetry codes: (ii) } \frac{1}{2}+x, \frac{1}{2}-y, z ; \text { (iii) } \frac{1}{2}-x, y-\frac{1}{2}, 1-z ; \text { (iv) } \\
\frac{1}{2}-x, y-\frac{1}{2},-z ; \text { (v) } \frac{1}{2}-x, \frac{1}{2}+y,-z \text {. }\end{array}$} \\
\hline \multicolumn{5}{|c|}{ Table 3. Hydrogen-bonding geometry $\left(\AA,^{\circ}\right)$} \\
\hline$D-\mathrm{H} \cdots A$ & $D-\mathrm{H}$ & $\mathrm{H} \cdots A$ & $D \cdots A$ & $D-\mathrm{H} \cdots A$ \\
\hline $\mathrm{O} 5-\mathrm{H} 51 \cdots \mathrm{Ol}^{\prime \prime}$ & $0.81(4)$ & $1.93(4)$ & & $163(4)$ \\
\hline $\mathrm{O} 5-\mathrm{H} 52 \cdots \mathrm{O}^{\prime \prime}$ & $0.78(4)$ & $1.97(4)$ & $2.741(2)$ & 171 (4) \\
\hline $\mathrm{O} 5-\mathrm{H} 52 \cdots \mathrm{O} 2^{\mathrm{vi}}$ & $0.78(4)$ & $2.67(4)$ & $3.218(2)$ & $129(3)$ \\
\hline $\mathrm{O} 6-\mathrm{H} 61 \cdots \mathrm{O} 3^{\mathrm{vi}}$ & $0.63(4)$ & $2.63(4)$ & $3.059(2)$ & $128(4)$ \\
\hline $\mathrm{O} 6-\mathrm{H} 61 \cdots \mathrm{O}^{\prime \prime \prime i t}$ & $0.63(4)$ & $2.41(5)$ & $2.954(3)$ & $146(5)$ \\
\hline $\mathrm{O} 6-\mathrm{H} 62 \cdots \mathrm{Ol}^{\prime}$ & $0.90(3)$ & $1.98(4)$ & & $165(3)$ \\
\hline $\mathrm{O} 6-\mathrm{H} 62 \cdots \mathrm{O} 4^{\mathrm{int}}$ & $0.90(3)$ & $2.56(4)$ & $3.183(2)$ & $128(3)$ \\
\hline
\end{tabular}

Symmetry codes: (iii) $\frac{1}{2}-x, y-\frac{1}{2}, 1-z ;$ (iv) $\frac{1}{2}-x, y-\frac{1}{2},-z ;$ (vi) $x, y, z-1 ;$ (vii) $x, y-1, z ;$ (viii) $-x,-y, 1-z$

The coordinates published by Rumanova \& Malitskaja (1959) were taken as a starting model which was subsequently refined by full-matrix least-squares techniques.

Data collection: PW1100 control program. Cell refinement: LSUCRE (Appleman, 1995). Data reduction: XRAY80 (Stewart et al., 1980). Program(s) used to refine structure: SHELXL93 (Sheldrick, 1993).

This work was supported by the DGICYT (Spain) under project PB94-39. We thank Professor $M$. Martinez-Ripoll for the X-ray data collection.

Supplementary data for this paper are available from the IUCr electronic archives (Reference: BR 1219). Services for accessing these data are described at the back of the journal.

\section{References}

Appleman, D. E. (1995). US Geological Survey, Washington, DC, USA. Unpublished.

Bukin, V. I. \& Nozik, Y. Z. (1974). Zh. Strukt. Khim. 15, 712-716. 
Giglio, M. (1958). Acta Cryst. 11, 789-793.

Johnson, C. K. (1965). ORTEP. Report ORNL-3794. Oak Ridge National Laboratory, Tennessee, USA.

Nozik, Y. Z. \& Fykin, L. E. (1980). Eur. Crystallogr. Meet., p. 109.

Rumanova, I. M. \& Malitskaja, G. I. (1959). Kristallografiya, 4, 510525.

Sheldrick, G. M. (1993). SHELX93. Program for the Refinement of Crystal Structures. University of Göttingen, Germany.

Stewart, J. M., Kundell, F. A. \& Baldwin, J. C. (1980). The XRAY80 System. Computer Science Center, University of Maryland, College Park, Maryland, USA.

Vizcayno, C., Garcia-Gonzalez, M. T., Gutierrez, M. \& Rodriguez, R. (1995). Geoderma, 68, 193-210.

Acta Cryst. (1999). C55, 11-13

\section{Cobalt(II) trisodium hexamolybdoperiodate tetradecahydrate}

\author{
Cristina Rosu $^{a}$ and Michael H. Dickman ${ }^{b}$ \\ ${ }^{a}$ Department of Chemistry, Babes-Bolyai University, \\ RO-3400 Cluj-Napoca, Romania, and ${ }^{b}$ Department of \\ Chemistry, Georgetown University, Washington, DC 20057, \\ USA.E-mail:michaeld42@aol.com
}

(Received 20 October 1997; accepted I September 1998)

\begin{abstract}
In the title salt, $\mathrm{CoNa}_{3}\left[\mathrm{IMo}_{6} \mathrm{O}_{24}\right] \cdot 14 \mathrm{H}_{2} \mathrm{O}$, the anion has the Anderson structure with crystallographic $\overline{3} m$ symmetry. The unique cation site is occupied by disordered $\mathrm{Na}^{+}$and $\mathrm{Co}^{2+}$ ions. The I-O bond length is $1.890(4) \AA$. There are three types of Mo-O distances at 1.711 (4), 1.933 (2) and 2.352 (3) $\AA$, corresponding to terminal O atoms, $\mathrm{O}$ atoms bridging to other $\mathrm{Mo}^{6+}$ ions and those bridging to $\mathrm{I}^{7+}$ ions, respectively. The anions form layers perpendicular to the $c$ axis which are separated by double layers of cations.
\end{abstract}

\section{Comment}

The present study was undertaken as part of an investigation of the interaction of transition metals with polyoxometalate anions. Elemental analysis indicated one Co atom per six Mo atoms and the structure determination was performed to elucidate the role of cobalt in the salt.

The resulting structure (Fig. 1) reveals $\left[\mathrm{IMo}_{6} \mathrm{O}_{24}\right]^{5-}$ anions with crystallographic $\overline{3} m$ symmetry. The anion has the well known Anderson structure (Pope, 1983), consisting of a central octahedron surrounded in a planar fashion by six additional octahedra. The anion is surrounded by cations above and below the plane of the anion. The anion structure was originally proposed for $\left[\mathrm{IMo}_{6} \mathrm{O}_{24}\right]^{5-}$ and similar hexametalates (Anderson, 1937) and later confirmed for $\left[\mathrm{TeMo}_{6} \mathrm{O}_{24}\right]^{6-}$ (Evans,
1948). For a review of the history of these and other polyoxometalates, see Baker \& Glick (1998). Recent structural determinations of similar salts include $\left[\mathrm{NH}_{4}\right]_{4}$ $\left[\mathrm{Zn}(\mathrm{OH})_{6} \mathrm{Mo}_{6} \mathrm{O}_{18}\right] \cdot 6 \mathrm{H}_{2} \mathrm{O}$ (Allen et al., 1997) and [Ga$\left.\left(\mathrm{H}_{2} \mathrm{O}\right)_{6}\right]\left[\mathrm{Co}(\mathrm{OH})_{6} \mathrm{Mo}_{6} \mathrm{O}_{18}\right]$ (Panneerselvam et al., 1996). These salts contain protons on the triply bridging $\mathrm{O}$ atoms, which is typical for Anderson ions with central atoms having a charge of +3 or +2 .

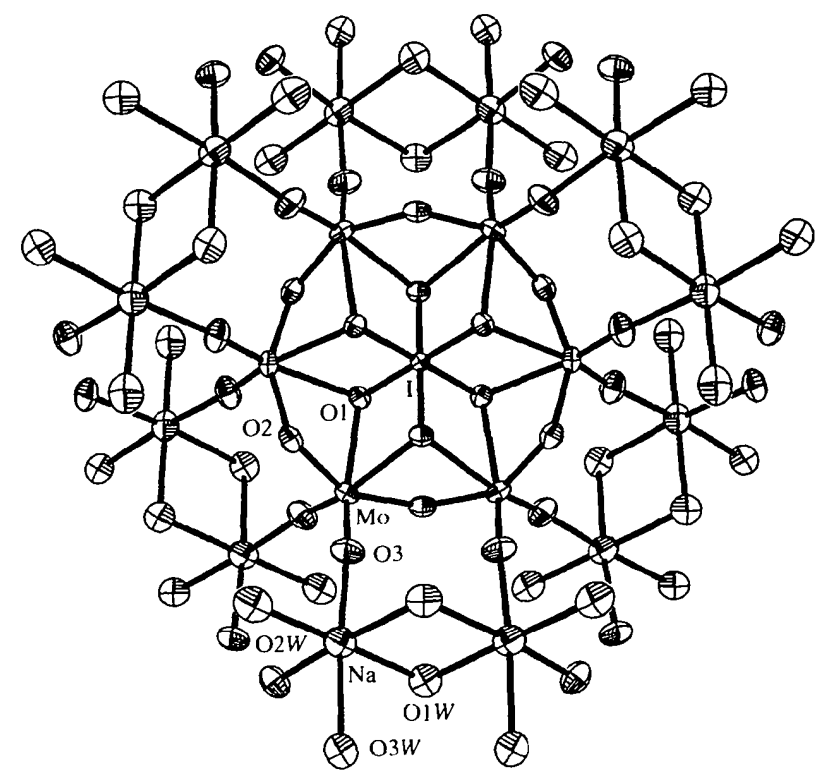

Fig. 1. View of the title compound, perpendicular to the $c$ axis showing the numbering scheme. Anisotropic displacement ellipsoids are shown at the $50 \%$ probability level.

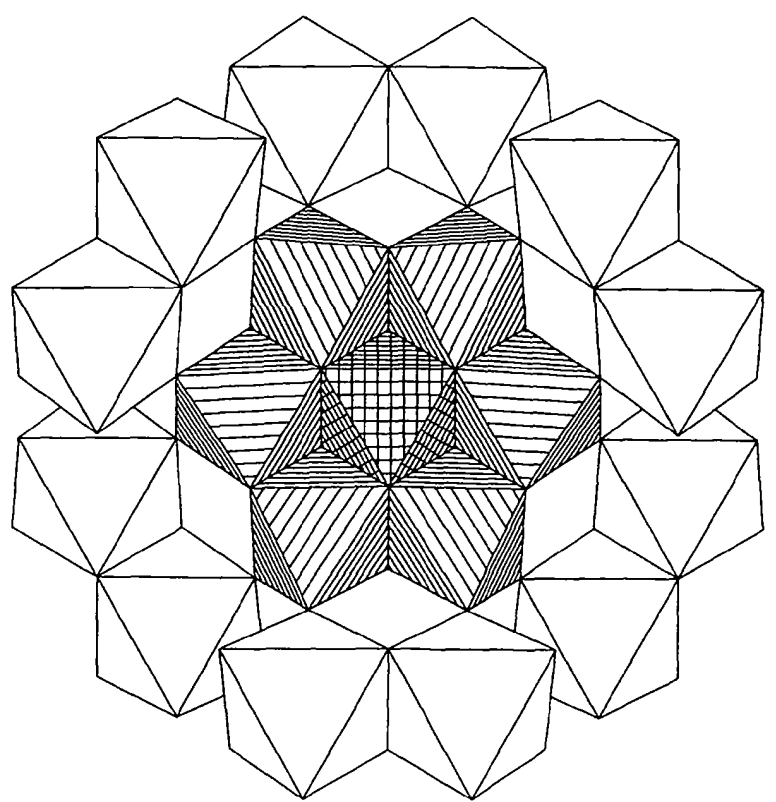

Fig. 2. Polyhedral representation of the title compound; vertices represent $\mathrm{O}$ atoms. 